\title{
Averrhoa carambola: A Renewable Source of Oxalic Acid for the Facile and Green Synthesis of Divalent Metal (Fe, Co, Ni, Zn, and $\mathrm{Cu}$ ) Oxalates and Oxide Nanoparticles
}

\author{
Nguimezong Nguefack Marius Borel, ${ }^{1}$ Josepha Foba-Tendo, ${ }^{1}$ Divine Mbom Yufanyi, ${ }^{1}$ \\ Ekane Peter Etape, ${ }^{1}$ Jude Namanga Eko, $^{2}$ and Lambi John Ngolui $^{3}$ \\ ${ }^{1}$ Department of Chemistry, Faculty of Science, University of Buea, P.O. Box 63, Buea, Cameroon \\ ${ }^{2}$ Institute of Physics, Department of Chemical Physics and Material Science, University of Augsburg, 86153 Augsburg, Germany \\ ${ }^{3}$ Department of Chemistry, E.N.S. Yaounde, P.O. Box 47, Yaounde, Cameroon \\ Correspondence should be addressed to Josepha Foba-Tendo; jnfoba@gmail.com
}

Received 27 June 2014; Accepted 2 September 2014; Published 17 September 2014

Academic Editor: Hongxing Dai

Copyright (C) 2014 Nguimezong Nguefack Marius Borel et al. This is an open access article distributed under the Creative Commons Attribution License, which permits unrestricted use, distribution, and reproduction in any medium, provided the original work is properly cited.

\begin{abstract}
A green, simple, and environmentally benign synthetic approach has been utilised to obtain some bivalent metal oxalates from Averrhoa carambola juice extract, without any purification or special treatment of the juice. The main acid components (oxalic acid and ascorbic acid) of the juice were identified by HPLC technique. The effect of temperature on the purity of the product has been investigated. The as-synthesized metal oxalates were thermally decomposed at low temperatures to their respective metal oxide nanoparticles. The metal oxalates and their respective thermal decomposition products were characterized by Fourier Transform Infrared spectroscopy, X-ray diffraction analysis, and thermogravimetry.
\end{abstract}

\section{Introduction}

Metal carboxylates have been widely investigated and have been used as precursors in the production of metal oxide nanomaterials [1-6]. Generally, these metal carboxylates are thermally decomposed at relatively low temperatures into the corresponding metal oxide nanomaterials. The precursors are usually obtained when the metal salt reacts with the free acid or any of its labile carboxylates. The reactants are generally synthetic, but many of these carboxylates are readily available in our environment (mostly in plants) and need only to be harnessed. They include, amongst others, citric acid, tartaric acid, and oxalic acid. The latter is known to be one of the major acids in many plants (e.g., Rhubarb and Averrhoa carambola).

Averrhoa carambola, known as carambola or star fruit, is an attractive, exotic, tropical, and shrub-like ornamental tree of the Oxalidaceae family [7-10]. The ripe fruits can be eaten fresh or used to produce juice, jelly, or wine [11].
The fruit is also widely used in traditional medicine for the treatment of a wide range of ailments $[10,12]$. It is also a potential source of pectin [12]. Carambola fruit juice has been shown $[7,13]$ to contain active constituents such as vitamins, amino acids, ascorbic acid, oxalic acid, tartaric acid, citric acid, carbohydrates, fats, and proteins. Assessment of the physicochemical properties of carambola fruit juice from ripe and unripe fruits showed that the $\mathrm{pH}$ of the fruits increased with advance in maturity, being 2.4 for green mature, 2.7 for half-ripe, and 3.44 for ripe fruits [7]. Averrhoa carambola is a very good source of oxalic acid, with oxalic acid contents that can be as high as $1 \mathrm{wt} \%$ of wet mass (representing about $74 \%$ of the total acid content depending on the level of maturity of the fruits) $[7,14,15]$.

The high concentration of oxalic acid in this fruit is responsible for its toxicity. Star fruit and other plants containing high amounts of oxalates can cause neurotoxic and nephrotoxic effects in humans and animals [16-19]. It will therefore be very useful to develop an approach that can 
reduce the amount of acid in the fruit prior to its consumption. We here explore the feasibility of using this naturally available and sustainable resource (Averrhoa carambola L.) rather than the commercial sources for the synthesis of metal oxalates. The use of these natural renewable resources is of environmental significance and in the case of free oxalic acid rich fruits (e.g., Averrhoa carambola L.) could result in a significant reduction in the level of the free acid, thus adding value to the elimination of toxic components through reaction with metal ions of biological and technological importance. This could also open up the possibility of high value exploitation of spoiled fruits.

In order to render the synthesis cost effective and ecofriendly, we decided to proceed with a synthetic pathway where the fruit juice is used directly without initial purification steps or prior extraction of the acid. This decision was guided by the fact that in the natural condition of the juice ( $\mathrm{pH}$ 2.6-3.1) oxalic acid has a better chance to react preferentially with the metal ions owing to its relative high acidic strength $\left(\mathrm{pKa}_{1}(1.23)\right.$ and $\mathrm{pKa}_{2}$ (4.19)). In comparison with the other carboxylic acids present in the juice, oxalic acid requires no initial alkaline deprotonation step to precipitate with the metal ions and the precipitation can therefore occur at the natural $\mathrm{pH}$ of the juice.

The synthesis of metal $(\mathrm{Mn}, \mathrm{Fe}, \mathrm{Co}, \mathrm{Ni}, \mathrm{Cu}, \mathrm{Zn}$, and Cd) oxalates by solvothermal [4], microemulsion [2], reverse micellar route [13], solid state route [20] and by single diffusion technique in agar gel [6] has been reported. These oxalate nanorods have been used as precursors for the synthesis of oxide nanoparticles. Thermal decomposition of these precursors in the temperature range $450-500^{\circ} \mathrm{C}$ yielded homogeneous oxide nanoparticles. In the different synthesis methods, a reaction of the appropriate metal salts and oxalic acid from commercial sources was used.

Herein we present a facile and green approach for the synthesis of metal oxalates and their subsequent thermal decomposition to the oxide nanoparticles. Our approach is based on mixing the metal ion solution and the fruit juice extract without the use of hazardous organic compounds or surfactants. In this preliminary study, five divalent $3 \mathrm{~d}$ metal ions $\left(\mathrm{Fe}^{2+}, \mathrm{Co}^{2+}, \mathrm{Ni}^{2+}, \mathrm{Zn}^{2+}\right.$, and $\left.\mathrm{Cu}^{2+}\right)$ were used for the proof of concept. The as prepared complexes and their various thermal decomposition products have been characterized by FTIR, powder XRD, and TGA.

\section{Experimental}

2.1. Chemicals. $\mathrm{Fe}(\mathrm{II}), \mathrm{Co}(\mathrm{II}), \mathrm{Ni}(\mathrm{II}), \mathrm{Cu}(\mathrm{II})$, and $\mathrm{Zn}(\mathrm{II})$ chlorides were obtained from Sigma Aldrich. The chemicals were of analytical grade and were used without further purification. HPLC grade oxalic, ascorbic, citric, lactic, malic, malonic, and succinic acids were also used.

2.2. Processing of the Fruit Juice. Ripe carambola fruits were harvested from the campus of CRTV Buea in the SouthWest Region of Cameroon. The fruits were washed under running tap water and crushed in a blender. The juice was extracted by squeezing through cheese cloth. The collected juice was centrifuged for $20 \mathrm{~min}$ at $3000 \mathrm{rpm}$, the supernatant
TABLE 1: Summary of sample codes, synthesis time, and colour of precipitates.

\begin{tabular}{lcc}
\hline Sample (code) & $\begin{array}{c}\text { Synthesis } \\
\text { time (min) }\end{array}$ & $\begin{array}{c}\text { Colour of } \\
\text { precipitate formed }\end{array}$ \\
\hline $\mathrm{Fe}^{2+}(\mathrm{P} 1)$ & 45 & Yellow \\
$\mathrm{Co}^{2+}(\mathrm{P} 2)$ & 30 & Pink \\
$\mathrm{Ni}^{2+}(\mathrm{P} 3)$ & 60 & Light green \\
$\mathrm{Cu}^{2+}(\mathrm{P} 5)$ & 60 & Light blue \\
$\mathrm{Zn}^{2+}(\mathrm{P} 4)$ & 60 & White \\
\hline
\end{tabular}

was filtered, and the filtrate collected and kept in a freezer for further use.

2.3. Characterization of the Juice. The acid content of the juice was investigated using HPLC. The HPLC system (DEGASY DG-1210) with an autosampler was coupled to a Gynkotek UV-detector (UVD340S) set at three wavelengths (214, 230, and $254 \mathrm{~nm}$ ). The data was collected and processed with Chromeleon software. The analyses were performed isocratically at $1.2 \mathrm{~mL} / \mathrm{min}$ at room temperature with an Altima C18 column $(250 \times 10 \mathrm{~mm}, 5 \mu \mathrm{m})$. The mobile phase was $0.1 \% \mathrm{~W} / \mathrm{V} \mathrm{H}_{3} \mathrm{PO}_{4}$ acidified distilled water. Standard solutions of several acids (oxalic, ascorbic, citric, lactic, malic, malonic, and succinic acids) were prepared and their chromatograms recorded as described above with a run time of $25 \mathrm{~min}$ and compared to that of the juice extract. Identification of the peaks enabled us to determine the nature of the acids contained in the juice. The amount of oxalic acid in the juice was determined by a spectrophotometric method based on the catalytic oxidation of bromophenol blue by dichromate using oxalic acid as the catalyst [21].

2.4. Synthesis of the Metal Oxalates. Prior to the synthesis, the $\mathrm{pH}$ of the juice was measured with Fisherdrand Hydrus $500 \mathrm{pH}$ meter.

Solutions $(0.1 \mathrm{M})$ of the various metal ions $\left(\mathrm{Fe}^{2+}, \mathrm{Co}^{2+}\right.$, $\mathrm{Ni}^{2+}, \mathrm{Zn}^{2+}$, and $\mathrm{Cu}^{2+}$ ) were prepared by dissolving the appropriate amount of the metal chloride in $100 \mathrm{~mL}$ distilled water. $30 \mathrm{~mL}$ of the juice extract was poured into a $250 \mathrm{~mL}$ round bottom flask immersed into a water bath maintained at $80^{\circ} \mathrm{C}$. The appropriate metal ion solution $(40 \mathrm{~mL})$ was added slowly into the juice while stirring, and the mixture was stirred for a given period of time, as summarized in Table 1 . The mixture was allowed to cool to room temperature and the precipitates obtained were filtered, washed several times with distilled water (to remove any undesired ions), allowed to airdry overnight, and finally dried in a desiccator over calcium chloride.

In order to study the effect of temperature on the synthesis product, we synthesized $\mathrm{Co}^{2+}$ complexes at various temperatures (room temperature, $45^{\circ} \mathrm{C}, 60^{\circ} \mathrm{C}$, and $80^{\circ} \mathrm{C}$ ) and compared their XRD patterns. Based on our observations $80^{\circ} \mathrm{C}$ was chosen as synthesis temperature for the precursors.

2.5. Thermal Decomposition of the Complexes. A sample of the dry precursor $(0.5 \mathrm{~g})$ was ground, placed in a ceramic 


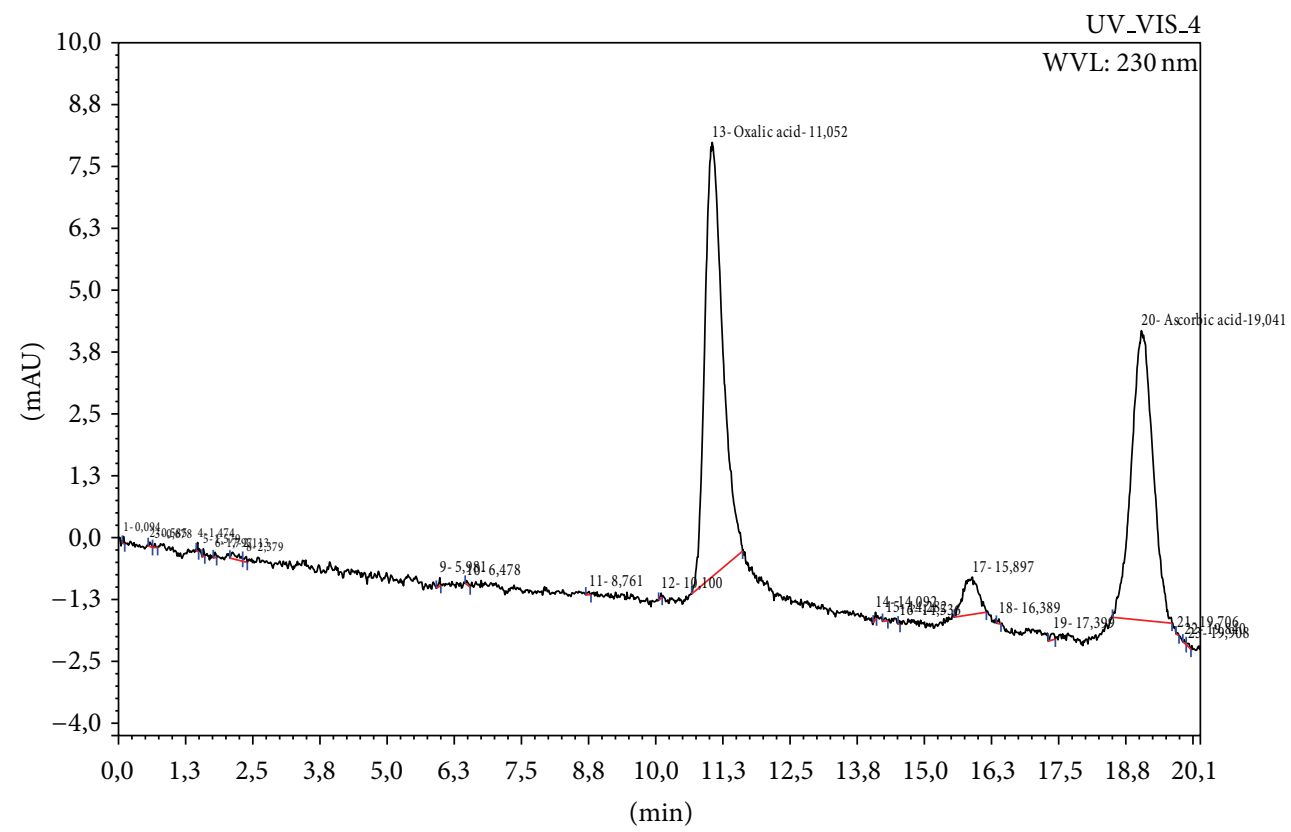

FIGURE 1: HPLC chromatogram of the juice.

crucible and the crucible was placed in the furnace that had been heated to the desired calcination temperature of $550^{\circ} \mathrm{C}$ and calcination in air continued for $4 \mathrm{~h}$. The sample was allowed to cool down to room temperature in the furnace. The residues (Dp1, Dp2, Dp3, and Dp4, resp., from P1, P2, P3, and P4) obtained were weighed and kept for further analyses. They represent, respectively, $43.9 \%, 44.4 \%, 42.9 \%$, and $40.9 \%$ of the precursors.

2.6. Characterization Techniques. FTIR spectra were recorded from 4000 to $400 \mathrm{~cm}^{-1}$ on a PerkinElmer Spectrum Two Universal Attenuated Total Reflectance Fourier Transform Infrared (UATR-FTIR) spectrometer. Thermogravimetric analysis (TGA) was obtained using a Pyris 6 PerkinElmer TGA 4000 thermal analyser. The TGA analysis was conducted between 30 and $900^{\circ} \mathrm{C}$ under nitrogen atmosphere at a flow rate of $20 \mathrm{~mL} / \mathrm{min}$ and a temperature ramp of $10^{\circ} \mathrm{C} / \mathrm{min}$. The XRD diffractograms of the precursors and the decomposition products were recorded on a Bruker $\mathrm{D} 8$ advance $\mathrm{X}$-ray diffractometer using a $\mathrm{Cu} \mathrm{K} \alpha$ radiation source $(\lambda=0.15406 \mathrm{~nm}, 40 \mathrm{kV}$, and $40 \mathrm{~mA})$. Scans were taken over the $2 \theta$ range from $10^{\circ}$ to $100^{\circ}$ in steps of $0.01^{\circ}$ at room temperature in open quartz sample holders. The phase was identified with the help of the BrukerDIFFRACplus evaluation software in combination with the ICDD powder diffraction data base (International Centre for Diffraction Data).

\section{Results and Discussion}

Reaction of the respective metal salts with the carambola juice at $80^{\circ} \mathrm{C}$ generally leads to coloured complexes (except the zinc complex, P4) in high yields. The metal complexes are less intense in colour than the respective metal salts from which they were derived. The complexes are crystalline solids that are air stable and nonhygroscopic as opposed to the starting salts. Physical data for the complexes are presented in Table 1.

3.1. HPLC Analysis of Juice Extract. Figure 1 shows the HPLC chromatogram of the juice. Only two peaks appear after 22 minutes of run. These peaks are compared with those of the standard oxalic acid (RT $10.966 \mathrm{~min}$ ) and ascorbic acid (RT $18.938 \mathrm{~min}$ ). The absence of the peaks of other acids indicates that they are either absent or if present they are in trace proportions. This observation supports that of several authors who found that the principal acids in the mature fruits are ascorbic and oxalic acids [7, 14, 15]. It has been observed that as the fruits mature the relative content of oxalic acid increases while that of other acids decrease $[7,15]$. The amount of oxalic acid in the juice as determined by spectrophotometry was found to be in the range of 7.6$11.6 \mathrm{gL}^{-1}$, in agreement with the literature reports where the content is generally in the range of 6.3 to $12 \mathrm{gL}^{-1}$ of the juice $[7,14]$. The $\mathrm{pH}$ of the juice was found to be in the range 2.6 to 3.1. This falls within the range observed by Patil et al. [7] and Narain et al. [15]. These authors both observed an increase of $\mathrm{pH}$ as the fruit mature.

3.2. FTIR Spectral Characterisation. The formation of pure oxalate phases is indicated by FTIR analysis. Figure 2((a)(e)) shows the FTIR spectra of all the metal complexes synthesized from carambola juice. They all exhibit similar characteristics and comparable patterns, except that of P5. The bands observed are similar to those reported in the literature for metal oxalate dihydrates [22, 23]. The broad band at $3343 \mathrm{~cm}^{-1}$ is attributed to the stretching vibration of the $\mathrm{O}-\mathrm{H}$ bond of water molecules of crystallisation. The absence of this band in the spectrum of the copper complex 


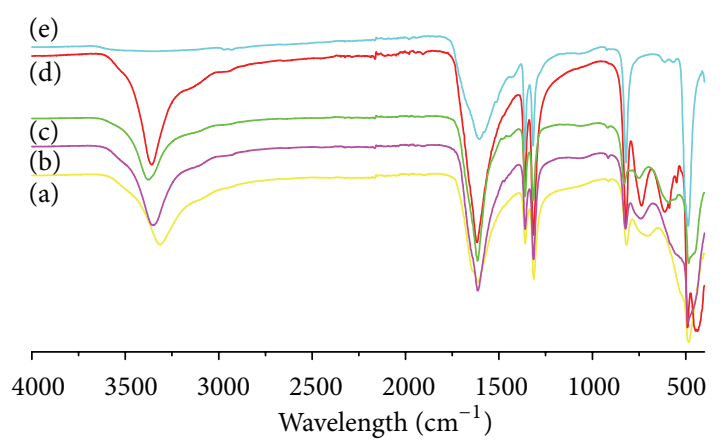

FIgURE 2: FTIR spectra of the complexes (spectra (a), (b), (c), (d), and (e) are for P1, P2, P3, P4, and P5, resp.).

(P5) attests to the reduced amount of water of crystallisation in this complex. The strong band at $1614 \mathrm{~cm}^{-1}$ is due to the antisymmetric stretching mode of the carbonyl group $\mathrm{C}=\mathrm{O}$ of the oxalate. The two bands at 1359 and $1314 \mathrm{~cm}^{-1}$ are those of $\mathrm{C}-\mathrm{O}$ symmetric stretching mode. The difference between $v_{\text {as }}(\mathrm{COO})$ and $v_{\text {sym }}(\mathrm{COO})$ stretching frequencies is $255 \mathrm{~cm}^{-1}$ indicating a bidentate or a terminal monodentate coordination mode of the oxalate ligand in the complexes [24]. The bands at $822 \mathrm{~cm}^{-1}$ is attributed to the bending vibration of $\mathrm{O}-\mathrm{C}-\mathrm{O}$ and the band at $745 \mathrm{~cm}^{-1}$ (absent in the spectrum of the $\mathrm{Cu}$ complex) is attributed to $\mathrm{H}-\mathrm{O}-\mathrm{H}$ rocking. The fact that no other bands are present attests to the identity and purity of the samples.

Figure 3((a)-(d)) shows the FTIR spectra of the decomposition products (DPi) of the various complexes. The bands present on the spectrum of the precursor complexes (Figure 2) have disappeared and new bands have appeared. The disappearance of the bands is attributed to the complete decomposition of the complexes. We observed the appearance of new bands in all the spectra suggesting the formation of new products. These bands are all around $500 \mathrm{~cm}^{-1}$ and are attributed to the stretching vibration of the $\mathrm{M}-\mathrm{O}$ bond. The spectra of Dp1 and Dp2 show two bands in this vicinity. In the case of cobalt product $(\mathrm{Dp} 2)$ the bands are at 660 and $550 \mathrm{~cm}^{-1}$ which suggest the formation of spinel $\mathrm{Co}_{3} \mathrm{O}_{4}$ that is $\left(\mathrm{Co}^{2+}\right)\left(\mathrm{Co}^{3+}\right)_{2}\left(\mathrm{O}^{2-}\right)_{4}$ [25]. These bands have been attributed, respectively, to $\left(\mathrm{Co}^{2+}\right)-\mathrm{O}-\left(\mathrm{Co}^{3+}\right)$ and to $\left(\mathrm{Co}^{3+}\right)-$ $\mathrm{O}-\left(\mathrm{Co}^{3+}\right)$ vibrations $[16-18,25]$. The presence of two bands instead of one or three bands in the spectrum of the iron product excludes the possibility of having $\mathrm{Fe}_{3} \mathrm{O}_{4}$ or $\gamma-\mathrm{Fe}_{2} \mathrm{O}_{3}$ and suggests that the product is likely to be pure $\alpha-\mathrm{Fe}_{2} \mathrm{O}_{3}$ $[19,26]$.

3.3. X-Ray Diffraction. The XRD spectra of the cobalt complexes synthesised at different temperatures are shown in Figure 4 . The observed XRD patterns are similar to that of the standard prepared from commercial oxalic acid as well as to those reported in the literature $[20,24]$. This indicates that cobalt oxalate dihydrate was obtained at the different synthesis temperatures. However, a close look at the XRD patterns reveals that some of the peaks such as (400) are not well resolved at lower temperatures (RT, 45 and $60^{\circ} \mathrm{C}$ ). The

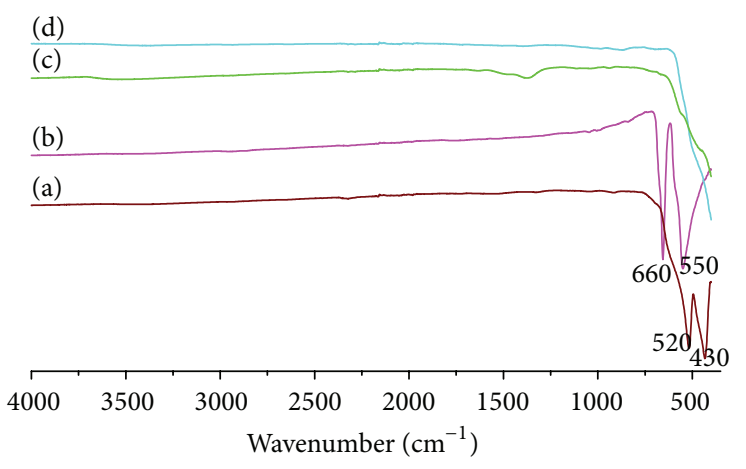

FIGURE 3: FTIR spectra of the thermal decomposition products (spectra (a), (b), (c), and (d) are for Dp1, Dp2, Dp3, and Dp4, resp.).

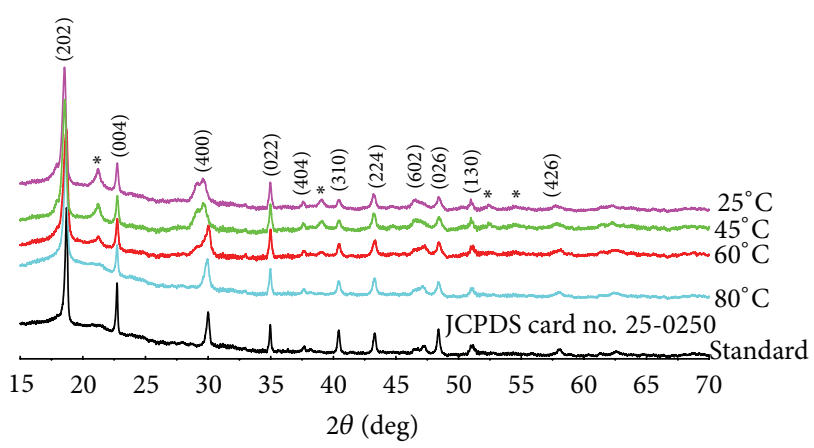

FIGURE 4: XRD patterns of CoOX synthesised at different temperatures.

spectra of the samples synthesized at lower temperatures also exhibit unidentified peaks $\left({ }^{*}\right)$. This suggests that despite the possibility to obtain the complexes at low temperatures, pure phases that compare to the standard are obtained at $80^{\circ} \mathrm{C}$. This prompted our decision to run all of the subsequent syntheses at $80^{\circ} \mathrm{C}$.

The XRD patterns of the metal complexes and their corresponding decomposition products are shown in Figure 5. The peaks have been indexed as shown on the spectra. The patterns of the complexes ( $\mathrm{al}, \mathrm{bl}, \mathrm{cl}$, and $\mathrm{d} 1$, respectively, for P1, P2, P3, and P4) are in good agreement with the JCPDS cards reported for the various metal oxalate dihydrates (except the pattern e which is not that of a dihydrate). The XRD spectrum of sample P1 matches the JCPDS card no 721305 for $\mathrm{FeC}_{2} \mathrm{O}_{4} \cdot 2 \mathrm{H}_{2} \mathrm{O}$ [19]. The XRD pattern of sample P2 matches the JCPDS card no $25-0250$ for $\beta-\mathrm{CoC}_{2} \mathrm{O}_{4} \cdot 2 \mathrm{H}_{2} \mathrm{O}$ $[20,24,27]$. The pattern of the nickel complex (P3) agrees with the JCPDS card no 14-0742 for $\mathrm{NiC}_{2} \mathrm{O}_{4} \cdot 2 \mathrm{H}_{2} \mathrm{O}$ [20]. The zinc complex is identified as $\mathrm{ZnC}_{2} \mathrm{O}_{4} \cdot 2 \mathrm{H}_{2} \mathrm{O}$ [28], its pattern agrees with JCPDS card no 25-1029, and the pattern of P5 is indexed in an orthorhombic cell with parameters described in JCPDS card no 21-0297 for $\mathrm{CuC}_{2} \mathrm{O}_{4} \cdot x \mathrm{H}_{2} \mathrm{O}(x<1)$ [20]. All of the peaks are attributed to the corresponding $\mathrm{M}^{\mathrm{II}} \mathrm{C}_{2} \mathrm{O}_{4} \cdot 2 \mathrm{H}_{2} \mathrm{O}$ and confirm that our products are the expected metal oxalates as already suggested from FTIR results.

The XRD pattern of the thermal decomposition products (Dp1, Dp2, Dp3, and Dp4) matched the patterns of the metal 


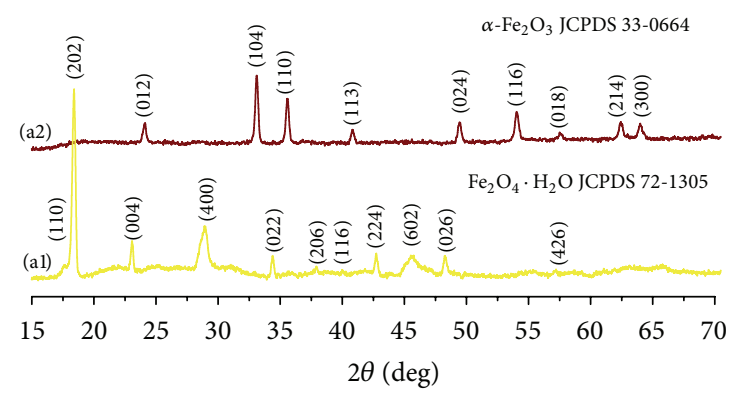

(a)

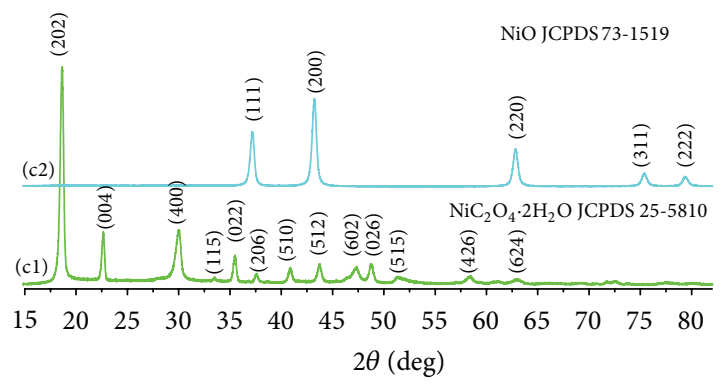

(c)

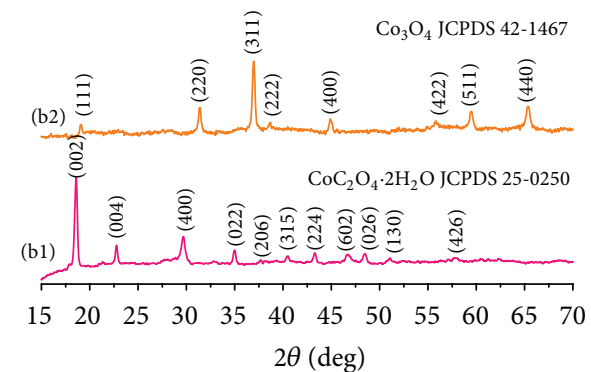

(b)

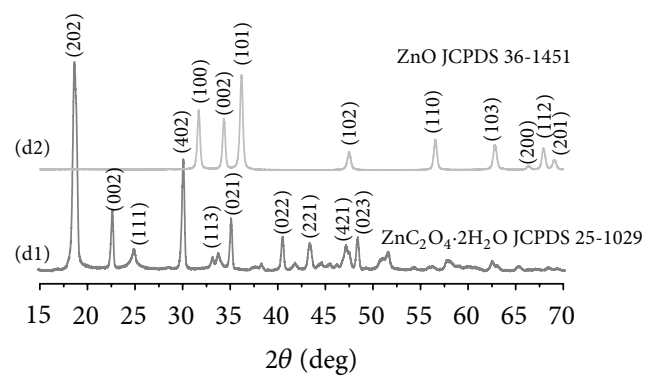

(d)

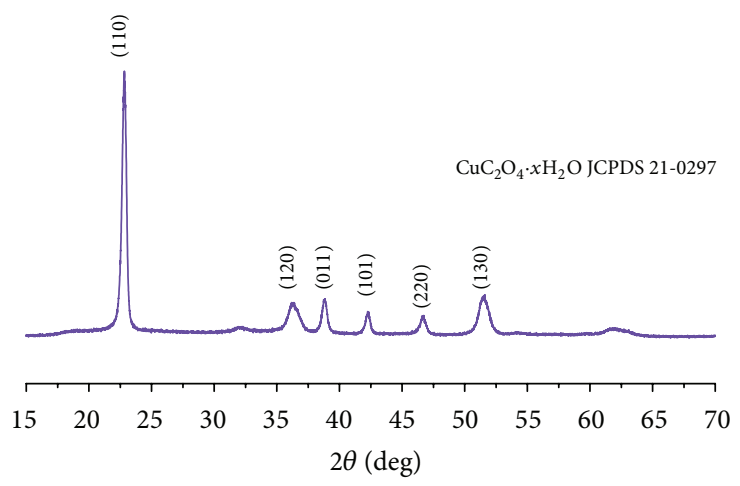

(e)

FIGURE 5: XRD spectra for the complexes (al-e) and of their decomposition products (a2-d2).

oxides as follows: the pattern of Dp1 compares with JCPDS card no 33-0664 for pure rhombohedral $\alpha-\mathrm{Fe}_{2} \mathrm{O}_{3}[19,26]$. The pattern of Dp2 compares with JCPDS card no 42-1467 for the spinel $\mathrm{Co}_{3} \mathrm{O}_{4}$ (space group: $\mathrm{Fd} 3 \mathrm{~m}$, lattice parameter) [27]. The pattern of Dp3 agrees with JCPDS card no 73-1519 for $\mathrm{NiO}$ [29] and the XRD pattern of Dp4 is indexed with respect to the parameters of JCPDS card no 36-1451 corresponding to $\mathrm{ZnO}[28,30]$. The purity of the products is evidenced by the absence of any impurity peaks.

The average crystallite sizes of the complexes were estimated using the Debye-Scherrer equation:

$$
D=\frac{0.9 \lambda}{\beta \cos \theta},
$$

where $\lambda$ is the wavelength of the $\mathrm{X}$-ray, $\beta$ is the full width at half maximum (FWHM) of the diffraction peak, and $\theta$ is the Bragg diffraction angle. The FWHM and the other parameters of the peaks were determined with OriginLab7 fitting wizard by using the Amplitude version of Gaussian peak function. Calculations were done with three peaks for each of the samples and averaged. The as-determined average particle sizes for both the complexes and their decomposition products are shown in Table 2 . The products are of nanometre size with average crystallite size in the range $14-25 \mathrm{~nm}$.

The thermograms of the complexes are shown in Figure 6 and summarised in Table 3. To better elucidate the thermal behaviour of the complexes, a graph of the weight difference for consecutive rows against the temperature was plotted (Figure 7). The thermograms of four of the complexes $\left(\mathrm{MC}_{2} \mathrm{O}_{4} \cdot x \mathrm{H}_{2} \mathrm{O}\right.$, where $\mathrm{M}=\mathrm{Fe}^{2+}, \mathrm{Co}^{2+}, \mathrm{Ni}^{2+}$, and $\left.\mathrm{Zn}^{2+}\right)$ show two well defined steps of weight loss in agreement with reports in literature $[24,28,31]$. The first weight loss for $\mathrm{FeC}_{2} \mathrm{O}_{4} \cdot x \mathrm{H}_{2} \mathrm{O}(20.9 \%)$ occurs in the range $170-218^{\circ} \mathrm{C}$. This is attributed to the elimination of two molecules of water of crystallization according to the theoretical value (19.69\%). The same is true for the first weight loss of $\mathrm{CoC}_{2} \mathrm{O}_{4} \cdot x \mathrm{H}_{2} \mathrm{O}$ 
TABLE 2: Average crystallite sizes of the complexes and their decomposition products obtained using Debye-Scherrer equation.

\begin{tabular}{|c|c|c|c|c|c|c|}
\hline \multirow{2}{*}{ Metal ion } & \multicolumn{3}{|c|}{ Metal oxalate } & \multicolumn{3}{|c|}{ Metal oxide } \\
\hline & Peak & Size $(\mathrm{nm})$ & Average (nm) & Peak & Size $(\mathrm{nm})$ & Average (nm) \\
\hline \multirow{3}{*}{$\mathrm{Fe}^{2+}$} & (202) & 23.08 & \multirow{3}{*}{24.9} & $(012)$ & 23.34 & \multirow{3}{*}{22.6} \\
\hline & (224) & 27.10 & & (104) & 24.35 & \\
\hline & $(022)$ & 24.57 & & $(024)$ & 21.03 & \\
\hline \multirow{3}{*}{$\mathrm{Co}^{2+}$} & $(002)$ & 21.65 & \multirow{3}{*}{22.5} & $(220)$ & 21.74 & \multirow{3}{*}{20.3} \\
\hline & $(022)$ & 24.06 & & (311) & 21.98 & \\
\hline & $(224)$ & 21.67 & & $(400)$ & 17.23 & \\
\hline \multirow{3}{*}{$\mathrm{Ni}^{2+}$} & $(202)$ & 17.42 & \multirow{3}{*}{19.7} & (111) & 14.80 & \multirow{3}{*}{14.5} \\
\hline & $(004)$ & 22.54 & & $(200)$ & 14.50 & \\
\hline & $(022)$ & 19.17 & & $(220)$ & 14.05 & \\
\hline \multirow{3}{*}{$\mathrm{Zn}^{2+}$} & $(002)$ & 24.64 & \multirow{3}{*}{23.3} & $(100)$ & 20.72 & \multirow{3}{*}{19.3} \\
\hline & $(402)$ & 22.12 & & $(101)$ & 19.76 & \\
\hline & $(022)$ & 23.28 & & (102) & 17.40 & \\
\hline \multirow{3}{*}{$\mathrm{Cu}^{2+}$} & $(110)$ & 16.25 & \multirow{3}{*}{15.0} & & \multirow{3}{*}{ Not available } & \\
\hline & (011) & 15.99 & & & & \\
\hline & $(220)$ & 12.78 & & & & \\
\hline
\end{tabular}

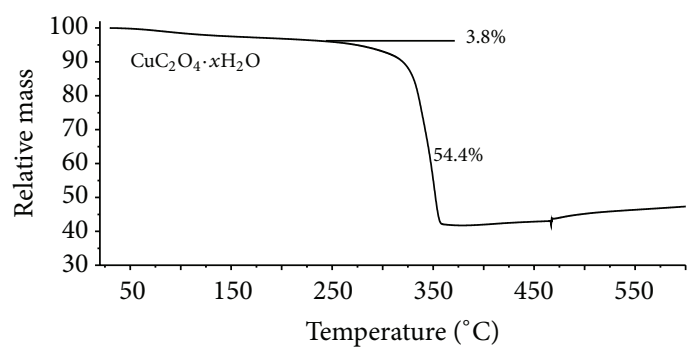

(a)

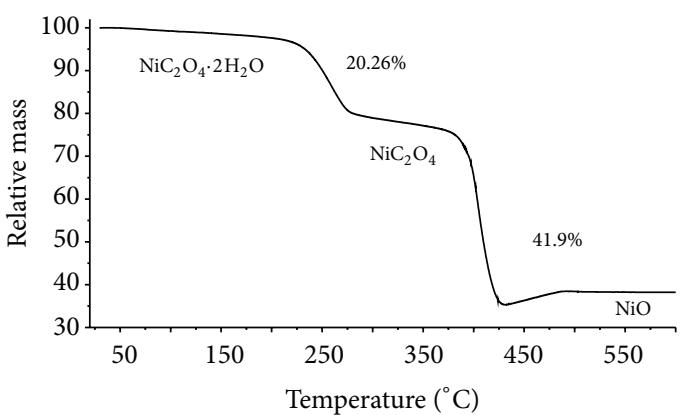

(c)

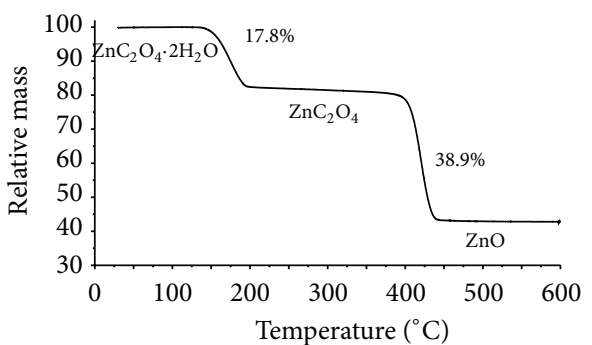

(b)

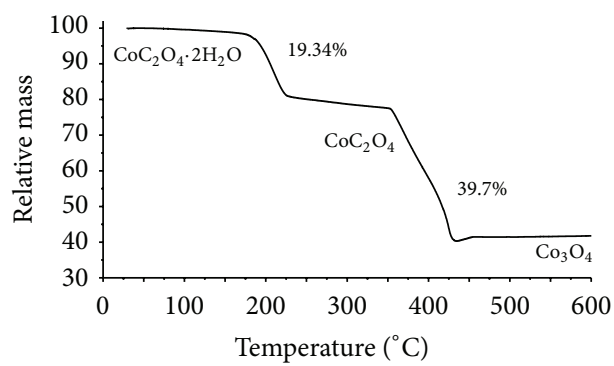

(d)

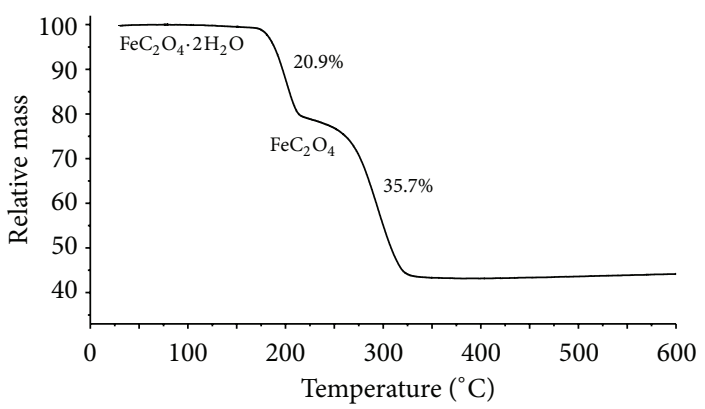

(e)

FIGURE 6: TG thermograms of the metal oxalates. 
TABle 3: Thermal decomposition temperatures and weight loss.

(a)

\begin{tabular}{|c|c|c|c|c|c|c|c|}
\hline & \multicolumn{3}{|c|}{ First weight loss } & \multicolumn{4}{|c|}{ Second weight loss } \\
\hline & Temp $\left({ }^{\circ} \mathrm{C}\right)$ & Obs. (\%) & Calc. (\%) & Temp. $\left({ }^{\circ} \mathrm{C}\right)$ & Obs. (\%) & Calc. (\%) & Possible $\mathrm{MO}_{x}$ formed \\
\hline \multirow{3}{*}{$\mathrm{FeC}_{2} \mathrm{O}_{4} \cdot 2 \mathrm{H}_{2} \mathrm{O}$} & & & & & & 40.03 & $\mathrm{FeO}$ \\
\hline & $170-218$ & 20.9 & 20.95 & $242-330$ & 35.7 & 35.59 & $\mathrm{Fe}_{2} \mathrm{O}_{3}$ \\
\hline & & & & & & 37.07 & $\mathrm{Fe}_{3} \mathrm{O}_{4}$ \\
\hline \multirow{3}{*}{$\mathrm{CoC}_{2} \mathrm{O}_{4} \cdot 2 \mathrm{H}_{2} \mathrm{O}$} & & & & & & 39.36 & $\mathrm{CoO}$ \\
\hline & $170-232$ & 19.3 & 19.69 & $350-436$ & 39.7 & 34.99 & $\mathrm{Co}_{2} \mathrm{O}_{3}$ \\
\hline & & & & & & 36.44 & $\mathrm{Co}_{3} \mathrm{O}_{4}$ \\
\hline $\mathrm{NiC}_{2} \mathrm{O}_{4} \cdot 2 \mathrm{H}_{2} \mathrm{O}$ & $210-285$ & 20.6 & 19.72 & $370-434$ & 41.9 & 39.41 & $\mathrm{NiO}$ \\
\hline $\mathrm{ZnC}_{2} \mathrm{O}_{4} \cdot 2 \mathrm{H}_{2} \mathrm{O}$ & $132-198$ & 17.8 & 19.02 & $385-445$ & 38.9 & 38.02 & $\mathrm{ZnO}$ \\
\hline
\end{tabular}

(b)

\begin{tabular}{|c|c|c|c|c|c|c|c|c|c|}
\hline & \multicolumn{4}{|c|}{ Sloppy weight loss } & \multicolumn{5}{|c|}{ Sharp weight loss } \\
\hline & Temp. $\left({ }^{\circ} \mathrm{C}\right)$ & Obs. (\%) & Calc. ( & ends on $x$ & Temp. $\left({ }^{\circ} \mathrm{C}\right)$ & Obs. (\%) & Calc. & ends on $x$ & $\mathrm{MO}_{x}$ \\
\hline \multirow{3}{*}{$\mathrm{CuC}_{2} \mathrm{O}_{4} \cdot x \mathrm{H}_{2} \mathrm{O}$} & & & $x=0$ & 0 & & & $x=0$ & 46.89 & \multirow{2}{*}{$\mathrm{CuO}$} \\
\hline & 272 & 3.8 & $x=1$ & 21.25 & $272-360$ & 54.4 & $x=1$ & 42.47 & \\
\hline & & & $x=0.3$ & 3.92 & & & $x=0.3$ & 55.5 & $\mathrm{Cu}$ \\
\hline
\end{tabular}

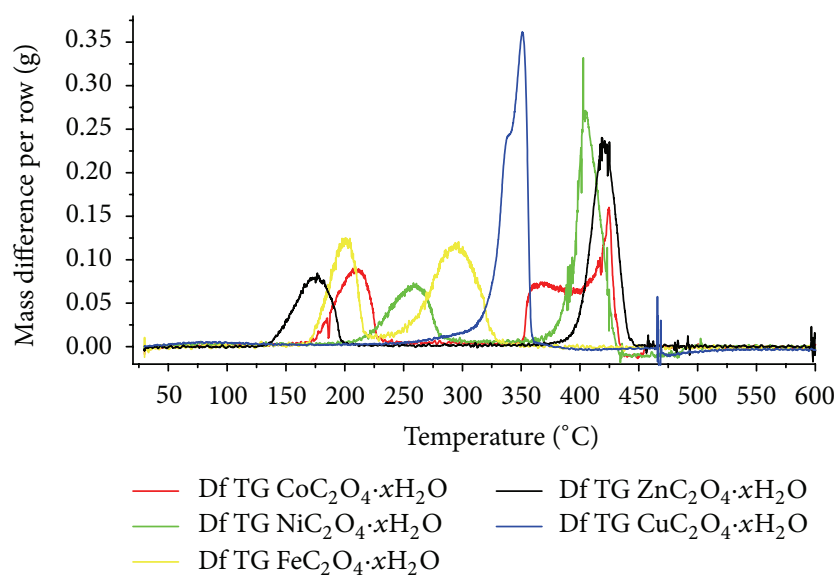

Figure 7: Df-TG plots of the difference in weight in consecutive rows against temperature.

$\left(19.34 \%, 170-232^{\circ} \mathrm{C}\right), \mathrm{NiC}_{2} \mathrm{O}_{4} \cdot x \mathrm{H}_{2} \mathrm{O}\left(20.61 \%, 210-285^{\circ} \mathrm{C}\right)$, and $\mathrm{ZnC}_{2} \mathrm{O}_{4} \cdot x \mathrm{H}_{2} \mathrm{O}\left(17.83 \%, 132-198^{\circ} \mathrm{C}\right)$ according to their respective theoretical values $(19.69 \%, 19.71 \%$, and $19.02 \%)$. This confirms the XRD observation that the complexes are metal oxalate dihydrates $\left(\mathrm{MC}_{2} \mathrm{O}_{4} \cdot 2 \mathrm{H}_{2} \mathrm{O}\right.$, where $\mathrm{M}=\mathrm{Fe}, \mathrm{Co}$, $\mathrm{Ni}$, or $\mathrm{Zn})$. The dehydration reaction can be written as follows:

$$
\mathrm{MC}_{2} \mathrm{O}_{4} \cdot 2 \mathrm{H}_{2} \mathrm{O} \longrightarrow \mathrm{MC}_{2} \mathrm{O}_{4}+2 \mathrm{H}_{2} \mathrm{O} \text {. }
$$

On the other hand, the thermogram of $\mathrm{CuC}_{2} \mathrm{O}_{4} \cdot x \mathrm{H}_{2} \mathrm{O}$ shows a single well-defined weight loss portion. There is a region of gradual weight loss (3.8\%) between 245 and $310^{\circ} \mathrm{C}$ immediately followed by the sharp portion hat end at $360^{\circ} \mathrm{C}$. This decomposition pattern has been observed by Jongen et al. [32]. The absence of a well-defined dehydration step suggests that there is a very little amount of water of crystallization in $\mathrm{CuC}_{2} \mathrm{O}_{4} \cdot x \mathrm{H}_{2} \mathrm{O}$. Using the observed weight loss, the amount of water was estimated and the following molecular formula proposed $\mathrm{CuC}_{2} \mathrm{O}_{4} \cdot 0.3 \mathrm{H}_{2} \mathrm{O}$. This agrees with its FTIR spectrum which shows no clear bands that can be assigned to water. The sharp weight loss portion on the thermogram of $\mathrm{CuC}_{2} \mathrm{O}_{4} \cdot 0.3 \mathrm{H}_{2} \mathrm{O}$ corresponds to $54.4 \%$ which is very close to $55.5 \%$ expected for the loss of two molecules of $\mathrm{CO}_{2}$ and the formation of metallic copper. As shown by the TG and Df-TG graphs, there is an increase in weight that occurs around $460^{\circ} \mathrm{C}$. We attribute this event to the oxidation of the metallic copper. As can be seen on Table 2 this is the process that best agrees with the observed values. This weight loss portion corresponds to the second weight loss portions of $\mathrm{FeC}_{2} \mathrm{O}_{4} \cdot x \mathrm{H}_{2} \mathrm{O}\left(35.7 \%\right.$, between 242 and $\left.330^{\circ} \mathrm{C}\right), \mathrm{CoC}_{2} \mathrm{O}_{4}$. $x \mathrm{H}_{2} \mathrm{O}\left(39.68 \%, 350-436^{\circ} \mathrm{C}\right), \mathrm{NiC}_{2} \mathrm{O}_{4} \cdot x \mathrm{H}_{2} \mathrm{O}(41.9 \%, 370-$ $\left.434^{\circ} \mathrm{C}\right)$, and $\mathrm{ZnC}_{2} \mathrm{O}_{4} \cdot x \mathrm{H}_{2} \mathrm{O}\left(38.9 \%, 385-445^{\circ} \mathrm{C}\right)$. As observed in the literature [28] some of these complexes will likely decompose in pathways which involve the decomposition of the anhydrous metal oxalate $\left(\mathrm{NiC}_{2} \mathrm{O}_{4}\right.$ and $\left.\mathrm{ZnC}_{2} \mathrm{O}_{4}\right)$ into ( $\mathrm{NiO}$ and $\mathrm{ZnO}$, resp.) with the elimination of $\mathrm{CO}_{2}$ and $\mathrm{CO}$. As for $\mathrm{FeC}_{2} \mathrm{O}_{4} \cdot 2 \mathrm{H}_{2} \mathrm{O}$ and $\mathrm{CoC}_{2} \mathrm{O}_{4} \cdot 2 \mathrm{H}_{2} \mathrm{O}$ this decomposition step might result in the production of a variety of products ( $\mathrm{MO}, \mathrm{M}_{2} \mathrm{O}_{3}$, or $\mathrm{M}_{3} \mathrm{O}_{4}$ ). The Df-TG of $\mathrm{CoC}_{2} \mathrm{O}_{4} \cdot 2 \mathrm{H}_{2} \mathrm{O}$ suggests that its second weight loss proceeds in two steps. Based on this observation and on the report made by $\mathrm{Wu}$ (2011) [33] we suggest that $\mathrm{CoC}_{2} \mathrm{O}_{4}$ undergoes both decomposition and oxidation reactions to produce $\mathrm{CO}_{2}$ and $\mathrm{Co}_{3} \mathrm{O}_{4}$ (3):

$$
3 \mathrm{CoC}_{2} \mathrm{O}_{4}+2 \mathrm{O}_{2} \longrightarrow \mathrm{Co}_{3} \mathrm{O}_{4}+6 \mathrm{CO}_{2}
$$

\section{Conclusion}

We have been able to use Averrhoa carambola juice as source of oxalic acid for the synthesis of some divalent metal oxalates. The synthesis required no special treatment of the juice as the product was obtained by directly mixing the metal 
ion solution and the juice. The products were all identified as the expected metal oxalates. Both the complexes and their decomposition products were found to be nanomaterials with their crystallite size ranging from 14 to $25 \mathrm{~nm}$.

\section{Conflict of Interests}

The authors declare that there is no conflict of interests regarding the publication of this paper.

\section{References}

[1] T. Palacios-Hernández, G. A. Hirata-Flores, O. E. ContrerasLópez et al., "Synthesis of $\mathrm{Cu}$ and Co metal oxide nanoparticles from thermal decomposition of tartrate complexes," Inorganica Chimica Acta, vol. 392, pp. 277-282, 2012.

[2] J. Ahmed, T. Ahmad, K. V. Ramanujachary, S. E. Lofland, and A. K. Ganguli, "Development of a microemulsion-based process for synthesis of cobalt (Co) and cobalt oxide (Co3O4) nanoparticles from submicrometer rods of cobalt oxalate," Journal of Colloid and Interface Science, vol. 321, no. 2, pp. 434-441, 2008.

[3] Y. Zhang, J. Zhu, X. Song, and X. Zhong, "Controlling the synthesis of $\mathrm{CoO}$ nanocrystals with various morphologies," Journal of Physical Chemistry C, vol. 112, no. 14, pp. 5322-5327, 2008.

[4] X. Wang, X. Chen, L. Gao, H. Zheng, Z. Zhang, and Y. Qian, "One-dimensional arrays of Co3O4 nanoparticles: Synthesis, characterization, and optical and electrochemical properties," Journal of Physical Chemistry B, vol. 108, no. 42, pp. 1640116404, 2004.

[5] D. N. Bhosale, V. M. S. Verenkar, K. S. Rane, P. P. Bakare, and S. R. Sawant, "Initial susceptibility studies on Cu-Mg-Zn ferrites," Materials Chemistry and Physics, vol. 59, no. 1, pp. 57-62, 1999.

[6] P. V. Dalal, "Nucleation controlled growth of cadmium oxalate crystals in agar gel and their characterization," Indian Journal of Materials Science, vol. 2013, Article ID 682950, 5 pages, 2013.

[7] A. G. Patil, D. A. Patil, A. V. Phatak, and N. Chandra, "Physical and chemical characteristization of carambola (averrhoa carambola L.) fruit at three stages of maturity," International Journal of Applied Biology and Pharmaceutical Technology, vol. 1, no. 2, pp. 624-629, 2010.

[8] P. Dasgupta, P. Chakraborty, and N. N. Bala, "Averrhoa carambola: an updated review," International Journal of Pharma Research and Review, vol. 2, no. 7, pp. 54-63, 2013.

[9] C. J. Wagner Jr., W. L. Bryan, R. E. Berry, W. Haven, and R. J. Knight Jr., "Carambola Selection for Commercial Production," Florida State Horticultural Society, vol. 88, pp. 466-469, 1975.

[10] G. Payal, K. Pankti, C. Manodeep, and K. V. Jagadish, "Phytochemical and pharmacological profile of averrhoa carambola Linn: an overview," International Research Journal of Pharmacy, vol. 3, no. 1, pp. 88-92, 2012.

[11] S. Napahde, A. Durve, D. Bharati, and N. Chandra, "Wine production from Carambola (Averrhoa carambola) juice using Saccharomyces cerevisiae," Asian Journal of Experimental Biological Science, pp. 20-23, 2010.

[12] A. Patil, S. Koli, D. Patil, and A. Phatak, "A comprehensive review of an important medicinal plant-Averrhoa carambola L," Pharmacognosy Communications, vol. 2, no. 2, pp. 13-17, 2012.

[13] A. Ganguly, P. Trinh, K. V. Ramanujachary, T. Ahmad, A. Mugweru, and A. K. Ganguli, "Reverse micellar based synthesis of ultrafine $\mathrm{MgO}$ nanoparticles (8-10 nm): characterization and catalytic properties," Journal of Colloid and Interface Science, vol. 353, no. 1, pp. 137-142, 2011.

[14] C. W. Wilson III, P. E. Shaw, and R. J. Knight Jr., "Analysis of oxalic acid in carambola (Averrhoa carambola L.) and spinach by high-performance liquid chromatography," Journal of Agricultural and Food Chemistry, vol. 30, no. 6, pp. 1106-1108, 1982.

[15] N. Narain, P. S. Bora, H. J. Holschuh, M. A. Da, and S. Vasconcelo, "Physical and chemical composition of carambola fruit (Averrhoa carambola L.) at three stages of maturity," Ciencia y Tecnología Alimentaria, vol. 3, no. 3, pp. 144-148, 2001.

[16] M. T. Makhlouf, B. M. Abu-Zied, and T. H. Mansoure, "Nanocrystalline $\mathrm{Co}_{3} \mathrm{O}_{4}$ fabricated via the combustion method," Metals and Materials International, vol. 19, no. 3, pp. 489-495, 2013.

[17] M. Salavati-Niasari, N. Mir, and F. Davar, "Synthesis and characterization of $\mathrm{Co}_{3} \mathrm{O}_{4}$ nanorods by thermal decomposition of cobalt oxalate," Journal of Physics and Chemistry of Solids, vol. 70, no. 5, pp. 847-852, 2009.

[18] T. Ozkaya, A. Baykal, M. S. Toprak, Y. Koseoğlu, and Z. Durmuş, "Reflux synthesis of $\mathrm{Co}_{3} \mathrm{O}_{4}$ nanoparticles and its magnetic characterization," Journal of Magnetism and Magnetic Materials, vol. 321, no. 14, pp. 2145-2149, 2009.

[19] N. Du, Y. Xu, H. Zhang, C. Zhai, and D. Yang, "Selective synthesis of $\mathrm{Fe}_{2} \mathrm{O}_{3}$ and $\mathrm{Fe}_{3} \mathrm{O}_{4}$ nanowires via a single precursor: a general method for metal oxide nanowires," Nanoscale Research Letters, vol. 5, no. 8, pp. 1295-1300, 2010.

[20] H. Luo, D. Zou, L. Zhou, and T. Ying, "Ionic liquid-assisted synthesis of transition metal oxalates via one-step solid-state reaction," Journal of Alloys and Compounds, vol. 481, no. 1-2, pp. L12-L14, 2009.

[21] X.-Q. Xu and Z.-Q. Zhang, "Kinetic spectrophotometric determination of oxalic acid based on the catalytic oxidation of bromophenol blue by dichromate," Mikrochimica Acta, vol. 135, no. 3-4, pp. 169-172, 2000.

[22] M. C. D’Antonio, A. Wladimirsky, D. Palacios et al., "Spectroscopic investigations of iron(II) and iron(III) oxalates," Journal of the Brazilian Chemical Society, vol. 20, no. 3, pp. 445-450, 2009.

[23] A. Wladimirsky, D. Palacios, M. C. D’Antonio, A. C. GonzaleaBaro, and E. J. Baran, "Vibratinal spectra of the $\alpha-\mathrm{M}^{I I}$ $\mathrm{C}_{2} \mathrm{O}_{4} \cdot 2 \mathrm{H}_{2} \mathrm{O}$ Oxalato complexes, with $\mathrm{M}^{I I}=\mathrm{Co}, \mathrm{Ni}, \mathrm{Zn}$," The Journal of the Argentine Chemical Society, vol. 98, pp. 71-77, 2011.

[24] E. Romero, M. E. Mendoza, and R. Escudero, "Weak ferromagnetism in cobalt oxalate crystals," Physica Status Solidi (B): Basic Research, vol. 248, no. 6, pp. 1519-1525, 2011.

[25] M. T. Makhlouf, B. M. Abu-Zied, and T. H. Mansoure, "Direct fabrication of cobalt oxide nanoparticles employing sucrose as a combustion fuel," Journal of Nanoparticles, vol. 2013, Article ID 384350, 7 pages, 2013.

[26] W. Qin, C. Yang, R. Yi, and G. Gao, "Hydrothermal synthesis and characterization of single-crystalline $\alpha-\mathrm{Fe}_{2} \mathrm{O}_{3}$ nanocubes," Journal of Nanomaterials, vol. 2011, Article ID 159259, 5 pages, 2011.

[27] L. Ren, P. Wang, Y. Han, C. Hu, and B. Wei, "Synthesis of $\mathrm{COC}_{2} \mathrm{O}_{4} \cdot 2 \mathrm{H}_{2} \mathrm{O}$ nanorods and their thermal decomposition to $\mathrm{CO}_{3} \mathrm{O}_{4}$ nanoparticles," Chemical Physics Letters, vol. 476, no. 13, pp. 78-83, 2009.

[28] L. Ni, L. Wang, B. Shao, Y. Wang, W. Zhang, and Y. Jiang, "Synthesis of flower-like zinc oxalate microspheres in ether-water 
bilayer refluxing systems and their conversion to zinc oxide microspheres," Journal of Materials Science and Technology, vol. 27, no. 6, pp. 563-569, 2011.

[29] V. P. Patil, S. Pawar, M. Chougoule et al., "Effect of annealing on structural, morphological, electrical and optical studies of nickel oxide thin films," Journal of Surface Engineered Materials and Advanced Technology, vol. 1, no. 2, pp. 35-41, 2011.

[30] C. Chen, B. Yu, P. Liu, J. F. Liu, and L. Wang, "Investigation of nano-sized $\mathrm{ZnO}$ particles fabricated by various synthesis routes," Journal of Ceramic Processing Research, vol. 12, no. 4, pp. 420-425, 2011.

[31] M. Hermanek, R. Zboril, M. Mashlan, L. MacHala, and O. Schneeweiss, "Thermal behaviour of iron(II) oxalate dihydrate in the atmosphere of its conversion gases," Journal of Materials Chemistry, vol. 16, no. 13, pp. 1273-1280, 2006.

[32] N. Jongen, H. Hofmann, P. Bowen, and J. Lemaître, "Calcination and morphological evolution of cubic copper oxalate particles," Journal of Materials Science Letters, vol. 19, no. 12, pp. 1073-1075, 2000.

[33] C.-H. Wu, "Preparation of ultrafine $\mathrm{Co}_{3} \mathrm{O}_{4}$ powders by continuous and controllable combustion synthesis," Transactions of Nonferrous Metals Society of China, vol. 21, no. 3, pp. 679-684, 2011. 

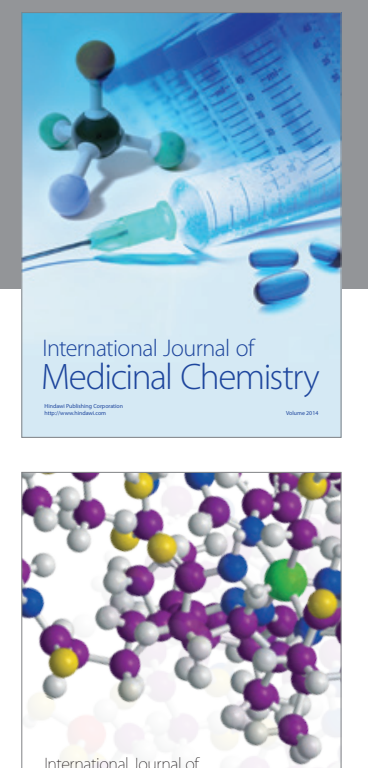

\section{Carbohydrate} Chemistry

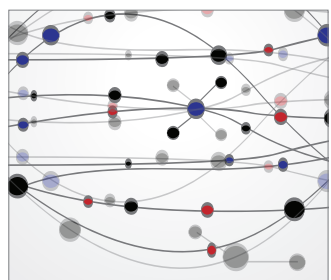

The Scientific World Journal
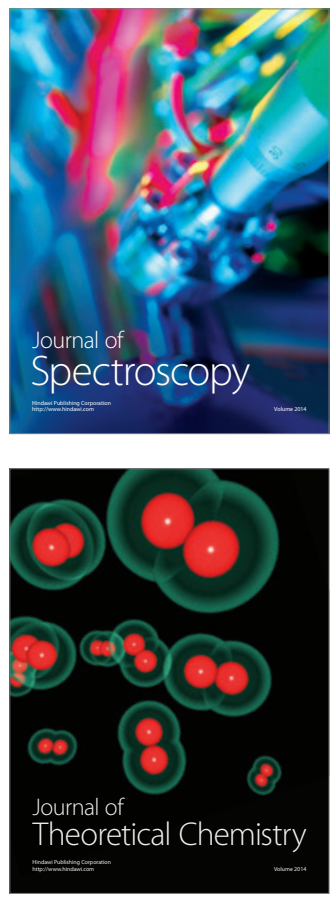
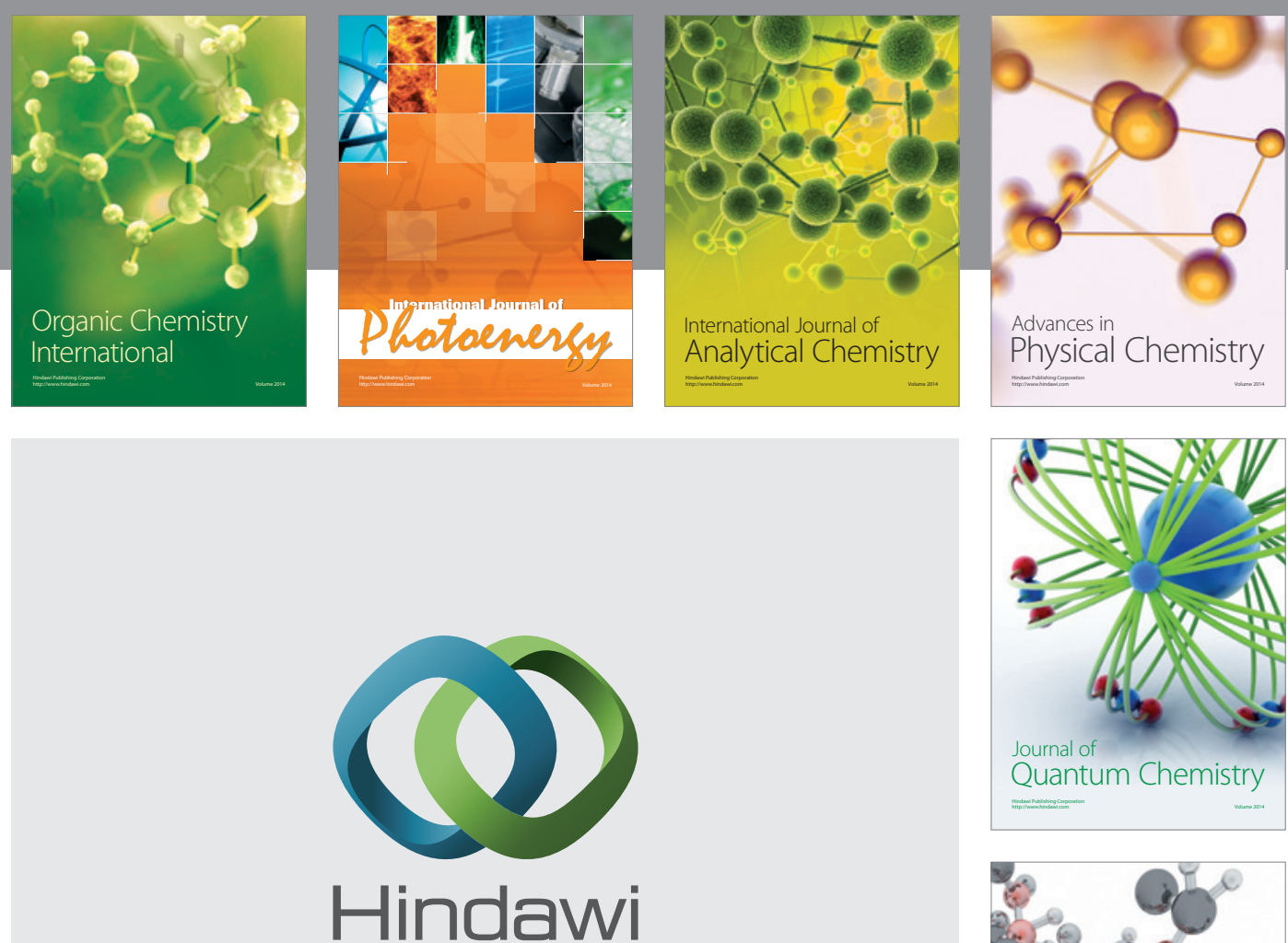

Submit your manuscripts at

http://www.hindawi.com

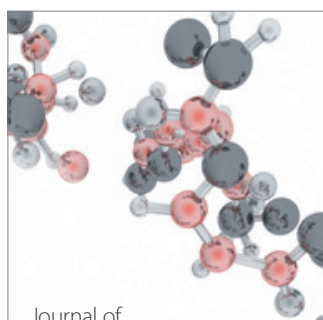

Analytical Methods

in Chemistry

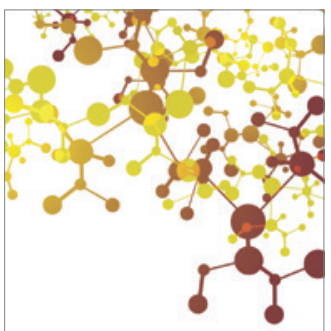

Journal of

Applied Chemistry

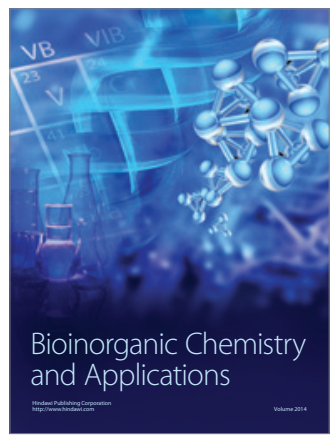

Inorganic Chemistry
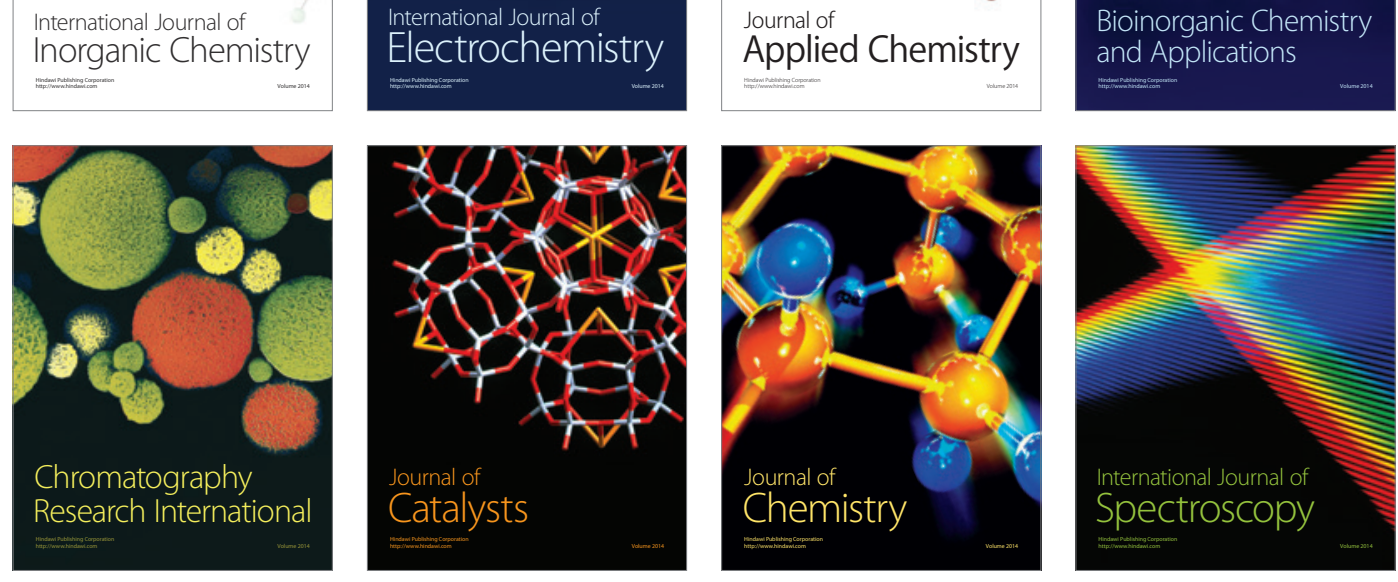